\title{
Investigation of Long-Term Climate and Streamflow Patterns in Ontario
}

\author{
Amin Azarkhish', Ramesh Rudra', Prasad Daggupati1, Jaskaran Dhiman 1* (1), \\ Trevor Dickinson ${ }^{1}$, Pradeep Goel ${ }^{2}$
}

\author{
${ }^{1}$ Water Resources Engineering, School of Engineering, University of Guelph, Guelph, Ontario, Canada \\ ${ }^{2}$ Ministry of the Environment, Conservation and Parks (MECP), Ontario, Canada \\ Email: dhimanj@uoguelph.ca
}

How to cite this paper: Azarkhish, A., Rudra, R., Daggupati, P., Dhiman, J., Dickinson, T., \& Goel, P. (2021). Investigation of Long-Term Climate and Streamflow Patterns in Ontario. American Journal of Climate Change, 10, 467-489.

https://doi.org/10.4236/ajcc.2021.104024

Received: June 28, 2021

Accepted: December 14, 2021

Published: December 17, 2021

Copyright (c) 2021 by author(s) and Scientific Research Publishing Inc. This work is licensed under the Creative Commons Attribution International License (CC BY 4.0).

http://creativecommons.org/licenses/by/4.0/

\begin{abstract}
To develop mitigation and adaptation strategies for undesired consequences of climate change, it is important to understand the changing hydrological and climatological trends in the past few decades. Although the changing climate is a cause of concern for the entire planet, its effects can vary significantly on a regional scale. Canada has experienced a rapid rise in the annual mean surface air temperature in the past decades. The current study aims to investigate trends in monthly mean precipitation, rainfall, snowfall, maximum and minimum temperature, as well as baseflow, surface runoff, and total streamflow values for the province of Ontario, Canada. To the best of the author's knowledge, a similar study involving rural and urban watersheds, that quantifies the impact of changing climate on temperature and other hydrological processes over a period ranging from 1968 to 2017, has not yet been conducted for Ontario. Man-Kendall trend test was used to analyze trends in the above mentioned climatic and hydrometric parameters for rural and urban watersheds situated in the northern and southern parts of Ontario. The results of this study indicate that the mean monthly minimum temperatures for rural watersheds situated in southern Ontario have increased significantly for the winter and summer months, which may have caused an increase in snowmelt and consequently the streamflow for the winter months in the region. Unlike the watersheds in southern Ontario, the northern watersheds witnessed relatively fewer instances of significant changes in mean monthly temperatures, and in some cases, declining rates have been noted. Similarly, only a few watersheds in the north saw a substantial drop in baseflow over the summer months. For nearly all the months, the average monthly minimum and maximum temperatures were found to increase for urban watersheds. The streamflow, baseflow, and surface runoff increased, likely due to rapid urbanization, resulting in a lower infiltration rate. These results will contri-
\end{abstract}


bute towards the decision-making processes and development of alternate water management policies within the province, taking into account the regional variations in climate change's impact on the hydrology of Ontario's watersheds.

\section{Keywords}

Climate Change, Hydrology, Ontario, Streamflow, Precipitation, Temperature

\section{Introduction}

Climate change has a wide range of potential social, economic, and environmental impacts. Global concerns related to rising sea levels (Church et al., 2013), increase in the frequency and intensity of heat waves (Peterson et al., 2013), and frequent flooding and drought events (Dai, 2013), makes it important to study the change in trends of climatic and hydrological data. However, the impacts of climate change along with land use changes on a regional scale may vary considerably based on geographic locations (Hamilton \& Keim, 2009). For instance, in a study conducted by Shahid et al. (2018) it was found that climate change along with land use change played an important role in decrease of runoff from the Soan basin, Pakistan. Thus, understanding the short and long-term effects of climate change on parameters such as temperature, precipitation, baseflow, surface runoff, and total streamflow at a regional scale becomes essential, especially for the local authorities and decision-makers (Shahid \& Rahman, 2021; Wang et al., 2016). The response of a local catchment to the climatic changes (e.g., variation in precipitation and temperature) is represented in its hydrologic regime. Also, the geomorphologic evolutions of catchments are much slower than the possible climatic variations being experienced. Thus, in the pristine watersheds with the unregulated flows, a stream's hydrologic regime can be a good indicator of the effects of climate change (Zhang et al., 2001).

The rate of increase in the annual mean temperature is almost twice the global warming rate in the northern regions of the planet (ACIA, 2005; AMAP-SWIPA, 2011). For the past few decades, Canada has experienced a rapid rise in the annual mean surface air temperature; there has been an increase of $1.5^{\circ} \mathrm{C}$ between years 1950 and 2010 (Vincent et al., 2012). A warming shift has also been observed for the Hudson Bay area from the year 1998 (Fazel-Rastgar, 2020). The province of Ontario, which is the most populous and the largest economy among all Canadian provinces, has been impacted considerably by regional climate change. For instance, in July 2013, a flood in Toronto caused the largest natural disaster ever recorded in the history of the province (Wang et al., 2014).

Based on the Fifth Assessment Report (AR5) of the Intergovernmental Panel on Climate Change, heavy precipitation followed an increasing trend between the mid-20th century and early 21st century in North America (Barros et al., 
2014). Studies conducted towards the end of the 20th century showed that in the last five decades of the century, the changes in annual precipitation within Canada have been between $-10 \%$ to $+35 \%$. The northern regions have experienced the strongest changes, whereas in south-eastern Canada, a significant decrease in winter precipitation was observed (Zhang et al., 2001). In higher latitudes, basins with snowmelt-flooding events are expected to witness changes in their flood frequencies (Burn \& Elnur, 2002).

For the past few decades, many researchers have studied the impacts of climate change on hydrology around the globe and within Canada. However, the results of these studies vary a lot depending on the location of the study; these results include both negative and positive trends in the hydrologic and climatic patterns (Nalley et al., 2012). Several studies have indicated increasing mean annual stream flows in Canada (Burn \& Elnur, 2002; McBean \& Motiee, 2006; Ehsanzadeh et al., 2007; Vincent et al., 2015), corresponding to increasing trends in temperature and precipitation (Barros et al., 2014; Wang et al., 2016; Whitfield \& Cannon, 2000). However, only a few studies have examined the long-term changes in surface runoff and baseflow of the streams in Ontario; these two hydrologic parameters correspond to different characteristics within each watershed, and their analyses can present a better view of the long-term impacts of changing climate on the hydrology of the watershed. There is also a need to investigate long term trends of climatic and hydrologic parameters in the urban watersheds.

Global climate change presents a real threat to human health, ecosystems, and water management systems; there is an urgent need to develop mitigation and adaptation strategies at local and global levels (Upadhyay, 2020). To be able to take any further steps in preparation and implementation of new strategies to mitigate the undesired consequences of the ongoing regional climate change in Ontario, it is essential to perform an updated and comprehensive study that analyzes the historical trends in hydrology and climatology of the province for the past few decades; the changing climate and its effects on hydrological processes can be assessed through a trend analysis of the location's historical climatic and hydrologic data (Shahid \& Rahman, 2021). Thus, the objective of this study is to understand the effects of the changing climate on hydrological process for rural and urban watersheds situated in northern and southern parts of Ontario.

\section{Materials and Methods}

\subsection{Data Selection}

In this study, we have looked at 13 rural and 2 urban watersheds within Ontario. Due to rapid urbanization in major Canadian cities, investigating the impacts of land use changes in urban watersheds on hydrologic responses in Ontario is one of the objectives of this study. For this purpose, two watersheds in the Greater Toronto Area (GTA) were also selected. The gross drainage areas for all the se- 
lected watersheds range from $183 \mathrm{~km}^{2}$ to $8570 \mathrm{~km}^{2}$. The outflow of each watershed is gauged at selected hydrometric stations, listed in Table 1. Among these, all but two of the stations belong to the Reference Hydrometric Basin Network (RHBN). The watersheds of RHBN stations have stable land-use conditions and are considered pristine with less than $5 \%$ of their area been altered (Cunderlik \& Burn, 2004; Cunderlik \& Ouarda, 2009).

Based on the information provided by Environment Canada, there are 1633 climate stations in Ontario with data available between 1840 and 2019. To investigate the variation in climatic parameters such as precipitation, rainfall, snowfall, average monthly minimum and maximum temperature, 20 meteorological stations were selected initially. However, some of the selected stations exhibited inconsistent or missing temporal data. Thus, the final results are limited to those climate stations which have consistent data available for a common period of time. To investigate the variation in climatic parameters, viz. precipitation,

Table 1. List of hydrometric stations for selected rural and urban watersheds in Ontario.

\begin{tabular}{|c|c|c|c|c|c|c|}
\hline$\#$ & ID & Station Name & Latitude & $\begin{array}{l}\text { Gross drainage } \\
\text { area }\left(\mathrm{km}^{2}\right)\end{array}$ & $\begin{array}{c}\text { Record } \\
\text { length } \\
(y r s)\end{array}$ & Remarks \\
\hline \multicolumn{7}{|c|}{ Rural Watersheds } \\
\hline 1 & 02GA010 & Nith river near Canning & $43^{\circ}$ & 1030 & 84 & \\
\hline 2 & 02FB007 & Sydenham river near Owen Sound & $44^{\circ}$ & 183 & 86 & \\
\hline 3 & 02HL004 & Skootamatta river near Actinolite & $44^{\circ}$ & 678 & 64 & $\begin{array}{l}1957 \text { seasonal } \\
\text { regulation }\end{array}$ \\
\hline 4 & $02 \mathrm{EC} 002$ & Black river near Washago & $44^{\circ}$ & 1510 & 106 & \\
\hline 5 & 02EA005 & North magnetawan river near Burk's Falls & $45^{\circ}$ & 329 & 104 & \\
\hline 6 & 02BF002 & Goulais river near Searchmont & $46^{\circ}$ & 1140 & 52 & \\
\hline 7 & $02 \mathrm{AB} 008$ & Neebing river near Thunder Bay & $48^{\circ}$ & 187 & 68 & \\
\hline 8 & 04LJ001 & Missinaibi river at Mattice & $49^{\circ}$ & 8570 & 99 & $\begin{array}{l}\text { Backwater due to } \\
\text { ice conditions }\end{array}$ \\
\hline 9 & 04JC002 & Nagagami river at Highway no. 11 & $49^{\circ}$ & 2180 & 69 & $\begin{array}{l}\text { Backwater due to } \\
\text { ice conditions }\end{array}$ \\
\hline 10 & 04MF001 & North French river near the Mouth & $51^{\circ}$ & 6680 & 53 & $\begin{array}{l}\text { Backwater due to } \\
\text { ice conditions }\end{array}$ \\
\hline 11 & 04DA001 & Pipestone river at Karl Lake & $52^{\circ}$ & 5960 & 53 & $\begin{array}{l}\text { Backwater due to } \\
\text { ice conditions }\end{array}$ \\
\hline 12 & 02GG002 & Sydenham river near Alvinston & $42^{\circ}$ & 701 & 73 & \\
\hline 13 & 02LA007 & Jock river near Richmond & $45^{\circ}$ & 526 & 51 & \\
\hline \multicolumn{7}{|c|}{ Urban Watersheds } \\
\hline 14 & 02HC030 & $\begin{array}{c}\text { Etobicoke creek below Queen } \\
\text { Elizabeth Highway }\end{array}$ & $43^{\circ}$ & 205 & 56 & \\
\hline 15 & $02 \mathrm{HC} 024$ & Don river at Todmorden & $43^{\circ}$ & 319 & 58 & Regulated flow \\
\hline
\end{tabular}


rainfall, snowfall, and average monthly minimum and maximum temperatures, these 13 meteorological stations were selected. Daily streamflow data is available for the selected stations, and it is used to estimate baseflow and surface runoff for the watersheds. Proximity to the selected watersheds, and availability and completeness of data for the selected time period were the key factors in finalizing the stations to be included in the study. For the results of the trend analysis to be acceptable, it is important to utilize data for a time period of 25 years or more (Burn \& Elnur, 2002). In this research, the minimum duration of the time period for which the data is available was 36 years; however, for most of the stations, 60 years of data was considered.

\subsection{Baseflow Separation}

To have a better understanding of variations in the streamflow, it is essential to separate the baseflow from the surface runoff. Various strategies can be followed to separate baseflow from surface runoff; these include graphical separation methods, filtering methods, frequency analysis methods, and recession analysis methods. One of the most commonly used methods for separating baseflow from the surface runoff is the one-parameter filter method proposed by Lyne and Hollick (1979). The results of a study performed by Rudra et al. (2015), showed that the digital filter method can generate more realistic baseflow hydrographs in the studied watersheds in southern Ontario. The equation for the one-parameter digital filter method used in the present study is given by Equation 1.

$$
b_{k}=a b_{k-1}+\frac{1-a}{2}\left(y_{k}+y_{k-1}\right) \quad b_{k} \leq y_{k}
$$

where, $y$ represents the total streamflow, $b$ represents baseflow, and $k$ represents the time-step number. Parameter $a$ is the filter parameter with a suggested value of 0.925; using this value in this equation gives realistic results (Arnold et al., 1995; Nathan \& McMahon, 1990).

\subsection{Trend Analysis}

The linear regression method is one of the simplest techniques for estimating the slope of a trend line in the data series. Linear least-square method is the most used technique for linear regression. However, very low and very high (extreme) values can considerably affect the results; this method, therefore, is not suitable for trend analysis of hydrologic and climatic parameters where the data consists of these low and high values. However, due to the simplicity of this method, it is one of the simplest ways to visualize the presence of trends in the data-series charts.

Man-Kendall test (Kendall, 1975; Mann, 1945) is also one of the most widely used trend tests to estimate nonparametric linear trends in hydrologic and climatic time-series (Cunderlik \& Ouarda, 2009). In comparison to the least-squares method, extreme values do not significantly affect the results of this test (Vin- 
cent et al., 2015). One of the limitations of the Mann-Kendall trend test is that the existence of statistically significant positive or negative serial correlation in the data-series can respectively cause overestimation or underestimation on the results of the test (Cunderlik \& Ouarda, 2009; Zhang et al., 2001). One of the most frequently used approaches to overcome this problem is the trend free pre-whitening (TFPW) method. The method was used to remove serial correlation by using Equation (2) (Cunderlik \& Ouarda, 2009; Von Storch \& Navarra, 1995; Zhang et al., 2001):

$$
x_{t}^{\prime}=x_{t+1}-A C_{1} x_{t}
$$

where, $x_{t}^{\prime}$ is the pre-whitened value of the time-series, $x_{t}$ is the original value of the time-series, and $A C_{1}$ is the lag-1 autocorrelation coefficient. The pre-whitening method is applied when there is a serial correlation in the time-series at a significance level of 0.05 .

Sen's non-parametric method was applied to estimate the slope of time-series. This method assumes that the data time-series has a linear trend. The slope (Q) of the trend can be calculated based on the slopes of all pairs of data. A positive value for $\mathrm{Q}$ shows an increasing trend and a negative value for $\mathrm{Q}$ represents a decreasing slope in the data-series. The Excel program MAKESENS (Salmi et al., 2002) was used to find the Sen's non-parametric slope of the data-series.

\section{Results}

Data from all flow, precipitation and temperature parameters collected from the hydrometric and climate stations were analyzed to identify trends. The results of the analysis for each of the rural and urban watersheds are presented in Table 2 and Table 3 respectively; statistically significant $(p<0.05)$ trends are indicated within the table. The time periods for the trend analyses were selected in a way that covered the maximum common duration for the data collected from different stations. Some of the climate stations provided data which did not lie between the selected duration; such data was not included in the current analysis. However, due to availability of the data, it is important to note that the time period selected for the comparison of the flow from different watersheds are slightly different from the common time period selected for comparing the climatic trends within each watershed.

\subsection{Rural Watersheds}

A total of 13 watersheds in the rural area across Ontario were investigated. Table 2 presents the results of the trend analysis for these selected watersheds. The watershed corresponding to the Sydenham river near Alvinston has two climate stations. However, as per the common time duration of the data provided by the hydrometric station of this watershed, only the Strathroy climate station was selected for analysis. Only the month of October was found to have an increasing trend in precipitation, and the rest of the months presented no significant trends. Also, no significant trends in the hydrometric parameters were observed 
Table 2. Significant trends in hydrometric and climatic parameters for rural watersheds in Ontario.

\begin{tabular}{|c|c|c|c|c|c|c|c|c|c|c|c|c|c|c|}
\hline \multirow{2}{*}{ Parameter } & \multirow{2}{*}{$\begin{array}{l}\text { Station } \\
\text { location }\end{array}$} & \multirow{2}{*}{$\begin{array}{l}\text { Station } \\
\text { name }\end{array}$} & \multicolumn{3}{|c|}{$\begin{array}{l}\text { Time period of } \\
\text { data used }\end{array}$} & \multicolumn{9}{|c|}{ Month of the year } \\
\hline & & & Start & End & $\begin{array}{l}\text { Duration } \\
\text { (years) }\end{array}$ & Jan Feb & Mar Apr & May & Jun & Jul & Aug & Sep & Oct Nov & Dec \\
\hline \multicolumn{15}{|c|}{ Watershed: Sydenham river near Alvinston, ID: 02GG002 } \\
\hline Streamflow & & Sydenham & 1968 & 2017 & 50 & & & & & & & & & \\
\hline Baseflow & & river near & 1968 & 2017 & 50 & & & & & & & & & \\
\hline Surface Flow & & Alvinston & 1968 & 2017 & 50 & & & & & & & & & \\
\hline Precipitation & Inside & & 1968 & 2017 & 50 & & & & & & & & $\uparrow$ & \\
\hline Rainfall & Inside & & 1968 & 2017 & 50 & & & & & & & & & \\
\hline Snowfall & Inside & Strathroy & 1968 & 2017 & 50 & & $\downarrow$ & * & * & * & * & * & * & \\
\hline Max Temp. & Inside & & 1968 & 2017 & 50 & & & & $\uparrow$ & & & $\uparrow$ & & \\
\hline Min Temp. & Inside & & 1968 & 2017 & 50 & & & & $\uparrow$ & $\uparrow$ & & & & \\
\hline \multicolumn{15}{|c|}{ Watershed: Nith river near Canning, ID: 02GA010 } \\
\hline Streamflow & & Nith river & 1973 & 2017 & 45 & $\uparrow$ & $\downarrow$ & & & $\uparrow$ & & & & \\
\hline Baseflow & & near & 1973 & 2017 & 45 & $\uparrow$ & & & & & & & & \\
\hline Surface Flow & & Canning & 1973 & 2017 & 45 & $\uparrow$ & $\downarrow$ & & & $\uparrow$ & & & & \\
\hline Precipitation & Outside & & 1973 & 2013 & 41 & & $\downarrow$ & & & & & & & \\
\hline Rainfall & Outside & & 1973 & 2013 & 41 & & $\downarrow$ & & & & & & & \\
\hline Snowfall & Outside & $\begin{array}{l}\text { Glen } \\
\text { Allan }\end{array}$ & 1973 & 2013 & 41 & & & * & * & * & * & * & * & \\
\hline Max Temp. & Outside & & 1973 & 2013 & 41 & & & & & & & $\uparrow$ & & \\
\hline Min Temp. & Outside & & 1973 & 2013 & 41 & & & & $\uparrow$ & $\uparrow$ & & $\uparrow$ & $\uparrow$ & \\
\hline Precipitation & Inside & & 1973 & 2017 & 45 & & & & & & & & & \\
\hline Rainfall & Inside & & 1973 & 2017 & 45 & & $\downarrow$ & & & & & & & \\
\hline Snowfall & Inside & Roseville & 1973 & 2017 & 45 & & & * & * & * & * & * & * & \\
\hline Max Temp. & Inside & & 1973 & 2017 & 45 & & & & & & & $\uparrow$ & & \\
\hline Min Temp. & Inside & & 1973 & 2017 & 45 & & & & $\uparrow$ & & & $\uparrow$ & $\uparrow$ & $\uparrow$ \\
\hline \multicolumn{15}{|c|}{ Watershed: Sydenham river near Owen Sound, ID: 02FB007 } \\
\hline Streamflow & & Sydenham & 1968 & 2017 & 50 & $\uparrow$ & & & & & & & & \\
\hline Baseflow & & $\begin{array}{l}\text { river near } \\
\text { Owen }\end{array}$ & 1968 & 2017 & 50 & $\uparrow$ & & & & & & & & \\
\hline Surface Flow & & Sound & 1968 & 2017 & 50 & & & & & & & & & \\
\hline Precipitation & Inside & & 1968 & 2013 & 46 & & & & & & & & $\uparrow$ & \\
\hline Rainfall & Inside & & 1968 & 2013 & 46 & & & & & & & & $\uparrow$ & \\
\hline Snowfall & Inside & Chatsworth & 1968 & 2013 & 46 & & & * & * & * & * & * & * & \\
\hline Max Temp. & Inside & & 1968 & 2013 & 46 & & & & & & & & & \\
\hline Min Temp. & Inside & & 1968 & 2013 & 46 & $\uparrow$ & & & $\uparrow$ & $\uparrow$ & & & & $\uparrow$ \\
\hline
\end{tabular}




\section{Continued}

\begin{tabular}{|c|c|c|c|c|c|c|c|c|c|c|c|c|c|c|c|c|}
\hline Precipitation & Outside & & 1968 & 2006 & 39 & & & & & & & $\downarrow$ & & & & \\
\hline Rainfall & Outside & Owen & 1968 & 2006 & 39 & & & & & & & $\downarrow$ & & & & \\
\hline Snowfall & Outside & Sound & 1968 & 2006 & 39 & & & & * & * & * & * & * & * & & \\
\hline Max Temp. & Outside & MOE & 1968 & 2006 & 39 & & & & & $\uparrow$ & & $\uparrow$ & & & & \\
\hline Min Temp. & Outside & & 1968 & 2006 & 39 & & & & $\uparrow$ & $\uparrow$ & $\uparrow$ & & & & & $\uparrow$ \\
\hline \multicolumn{17}{|c|}{ Watershed: Skootamatta river near Actinolite, ID: $02 \mathrm{HL} 004$} \\
\hline Streamflow & & Skootamatta & 1958 & 2017 & 60 & $\uparrow$ & $\uparrow$ & & $\downarrow$ & & & & & $\uparrow$ & & $\uparrow$ \\
\hline Baseflow & & river near & 1958 & 2017 & 60 & $\uparrow$ & $\uparrow$ & $\uparrow$ & $\downarrow$ & & & & & $\uparrow$ & & $\uparrow$ \\
\hline Surface Flow & & Actinolite & 1958 & 2017 & 60 & $\uparrow$ & & & & $\uparrow$ & & & & $\uparrow$ & & \\
\hline \multicolumn{17}{|c|}{ Watershed: Black river near Washago, ID: 02EC002 } \\
\hline Streamflow & & Black river & 1958 & 2006 & 49 & $\uparrow$ & $\uparrow$ & $\uparrow$ & & & & & & & & \\
\hline Baseflow & & near & 1958 & 2006 & 49 & $\uparrow$ & $\uparrow$ & $\uparrow$ & & & & & & & & \\
\hline Surface Flow & & Washago & 1958 & 2006 & 49 & $\uparrow$ & & & & & & & & & & \\
\hline Precipitation & Outside & & 1958 & 2006 & 49 & & & & & & & & & & & \\
\hline Rainfall & Outside & & 1958 & 2006 & 49 & & & & & & & & & & & \\
\hline Snowfall & Outside & Minden & 1958 & 2006 & 49 & & & & * & * & * & * & * & * & & \\
\hline Max Temp. & Outside & & 1958 & 2006 & 49 & & $\uparrow$ & $\uparrow$ & & $\uparrow$ & $\uparrow$ & $\uparrow$ & & & & $\uparrow$ \\
\hline Min Temp. & Outside & & 1958 & 2006 & 49 & & & & & $\uparrow$ & $\uparrow$ & $\uparrow$ & & & & $\uparrow$ \\
\hline Precipitation & Outside & & 1958 & 2006 & 49 & & & & $\uparrow$ & & & & & & & \\
\hline Rainfall & Outside & & 1958 & 2004 & 47 & & & & $\uparrow$ & & & & & & & \\
\hline Snowfall & Outside & Muskoka A & 1958 & 2004 & 47 & & & & * & * & * & * & * & & & \\
\hline Max Temp. & Outside & & 1958 & 2004 & 47 & & & & & & & & & & & $\uparrow$ \\
\hline Min Temp. & Outside & & 1958 & 2004 & 47 & & & & & $\uparrow$ & $\uparrow$ & $\uparrow$ & & & & \\
\hline \multicolumn{17}{|c|}{ Watershed: Jock river near Richmond, ID: 02LA007 } \\
\hline Stream Flow & & & 1970 & 2017 & 48 & $\uparrow$ & & & & $\uparrow$ & $\uparrow$ & & & & & \\
\hline Baseflow & & & 1970 & 2017 & 48 & & & & & & $\uparrow$ & $\uparrow$ & & & & \\
\hline Surface Flow & & & 1970 & 2017 & 48 & $\uparrow$ & & & & $\uparrow$ & & & & & & \\
\hline Precipitation & Outside & $\begin{array}{l}\text { Jock } \\
\text { river near }\end{array}$ & 1968 & 2017 & 50 & & & $\downarrow$ & & & & & & & $\downarrow$ & \\
\hline Rainfall & Outside & Richmond & 1968 & 2017 & 50 & & & & & & & & & & & \\
\hline Snowfall & Outside & & 1968 & 2017 & 50 & & & & * & * & * & * & * & * & $\downarrow$ & \\
\hline Max Temp. & Outside & & 1968 & 2017 & 50 & & & & & & & & $\uparrow$ & & $\uparrow$ & \\
\hline Min Temp. & Outside & & 1968 & 2017 & 50 & & & & & & & & & & & \\
\hline
\end{tabular}

Watershed: North Magnetawan river near Burk's Fall, ID: 02EA005

\begin{tabular}{lclllllll}
\hline Streamflow & North & 1958 & 2017 & 60 & $\uparrow$ & $\uparrow$ & $\uparrow$ & \\
Baseflow & $\begin{array}{c}\text { Magnetawan } \\
\text { river near }\end{array}$ & 1958 & 2017 & 60 & $\uparrow$ & $\uparrow$ & $\uparrow$ & \\
Surface Flow & Burk's Falls & 1958 & 2017 & 60 & $\uparrow$ & $\uparrow$ & & \\
\hline \multicolumn{7}{c}{ Watershed: Goulais river near Searchmont, ID: 02BF002 } \\
\hline Streamflow & $\begin{array}{c}\text { Goulais } \\
\text { river near }\end{array}$ & 1968 & 2017 & 50 & & $\downarrow$ & \\
Baseflow & Searchmont & 1968 & 2017 & 50 & & $\downarrow$ & $\downarrow$ \\
\hline
\end{tabular}


Continued

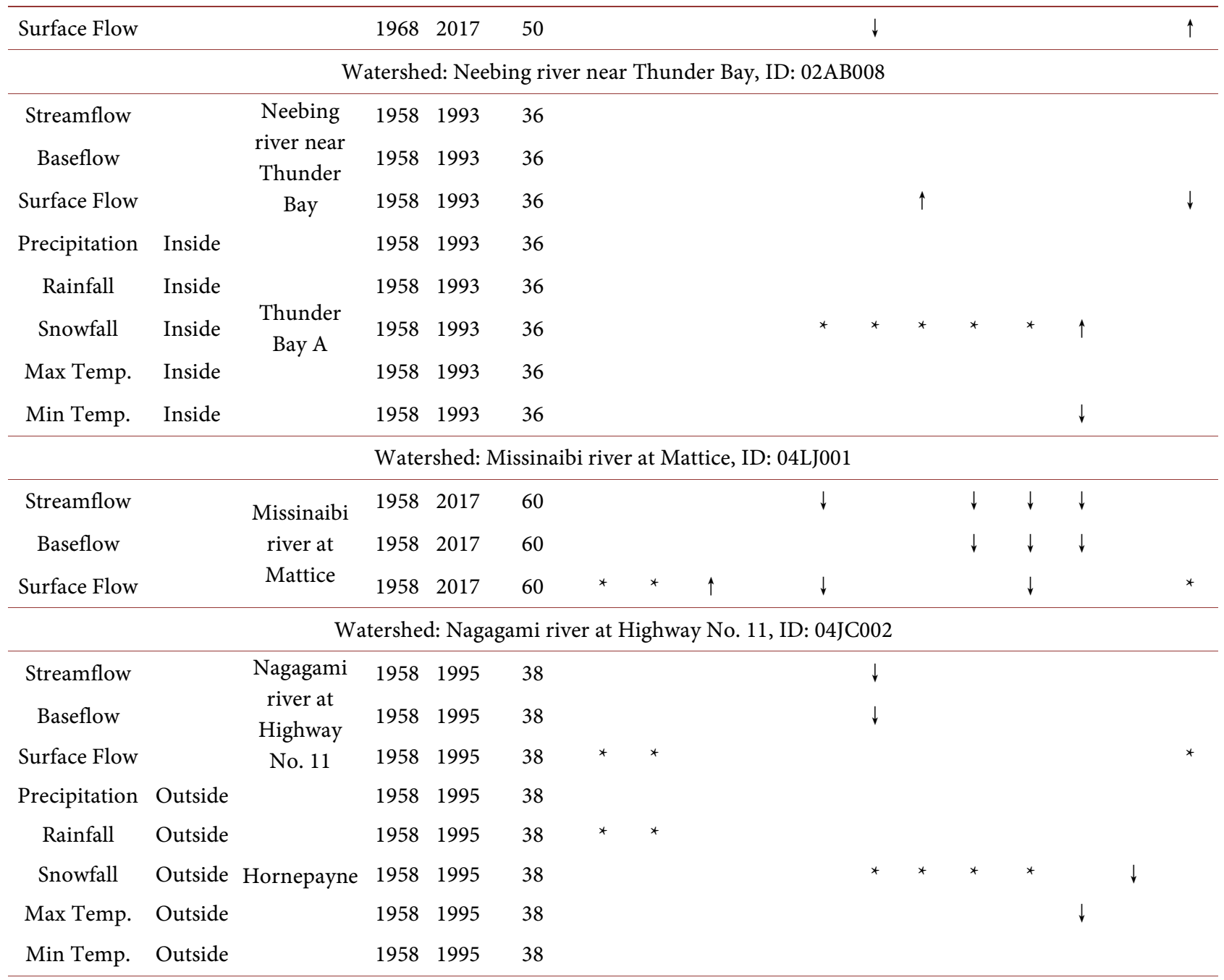

Watershed: North French river near The Mouth, ID: 04MF001

\begin{tabular}{|c|c|c|c|c|c|c|c|c|c|c|c|c|c|c|c|c|c|}
\hline Streamflow & & North & 1968 & 2017 & 50 & $\uparrow$ & $\uparrow$ & & & & & & & & & $\uparrow$ & $\uparrow$ \\
\hline Baseflow & & $\begin{array}{c}\text { French river } \\
\text { near }\end{array}$ & 1968 & 2017 & 50 & $\uparrow$ & $\uparrow$ & & $\uparrow$ & & & & & & & $\uparrow$ & $\uparrow$ \\
\hline Surface Flow & & The Mouth & 1968 & 2017 & 50 & * & * & $\uparrow$ & & & & & & & & $\uparrow$ & * \\
\hline Precipitation & Outside & & 1968 & 2017 & $50-3$ & & $\uparrow$ & & & & & & & & & & \\
\hline Rainfall & Outside & & 1968 & 2017 & $50-3$ & * & * & & & $\uparrow$ & & & & & & & $\downarrow$ \\
\hline Snowfall & Outside & $\begin{array}{c}\text { Moosonee } \\
\text { UA }\end{array}$ & 1968 & 2017 & $50-3$ & & $\uparrow$ & & & & * & * & * & * & $\downarrow$ & & \\
\hline Max Temp. & Outside & & 1968 & 2017 & $50-3$ & $\uparrow$ & & & & & & $\uparrow$ & & $\uparrow$ & & & \\
\hline Min Temp. & Outside & & 1968 & 2017 & $50-3$ & $\uparrow$ & $\uparrow$ & & & $\uparrow$ & & $\uparrow$ & $\uparrow$ & $\uparrow$ & $\uparrow$ & $\uparrow$ & $\uparrow$ \\
\hline \multicolumn{18}{|c|}{ Watershed: Pipestone river at Karl Lake, ID: 04DA001 } \\
\hline Streamflow & Inside & Pipestone & 1968 & 2016 & 49 & & & & & & & & & & & & \\
\hline Baseflow & Inside & river at & 1968 & 2016 & 49 & & & & & & & & & & & & \\
\hline Surface Flow & Inside & Karl Lake & 1968 & 2016 & 49 & * & * & & & & & & & & & & * \\
\hline
\end{tabular}

The upward arrow $(\uparrow)$ signifies a significant increasing trend, and the downward arrow $(\downarrow)$ signifies a significant decreasing trend $(\alpha=0.05)$. The asterisk symbol $\left.{ }^{*}\right)$ signifies presence of considerable number of "zero" values in the data that did not permit us to perform the trend analysis for the specified month. 
Table 3. Significant trends in hydrometric and climatic parameters for urban watersheds in Ontario.

\begin{tabular}{|c|c|c|c|c|c|c|c|c|c|c|c|c|c|c|c|c|c|}
\hline \multirow{2}{*}{ Parameter } & \multirow{2}{*}{$\begin{array}{l}\text { Station } \\
\text { location }\end{array}$} & \multirow{2}{*}{ Station name } & \multicolumn{3}{|c|}{$\begin{array}{l}\text { Time period } \\
\text { of data used }\end{array}$} & \multicolumn{12}{|c|}{ Month of the year } \\
\hline & & & Start & End & $\begin{array}{l}\text { Duration } \\
\text { (years) }\end{array}$ & Jan & Feb & Mar & Apr & May & Jun & Jul & Aug & Sep & Oct & Nov & Dec \\
\hline \multicolumn{18}{|c|}{ Watershed: Etobicoke Creek below Queen Elizabeth Highway, ID: 02HC030 } \\
\hline Streamflow & & $\begin{array}{c}\text { Etobicoke } \\
\text { Creek below }\end{array}$ & 1968 & 2017 & 50 & & & & & $\uparrow$ & $\uparrow$ & $\uparrow$ & $\uparrow$ & $\uparrow$ & $\uparrow$ & & \\
\hline Baseflow & & Queen & 1968 & 2017 & 50 & $\uparrow$ & & & & $\uparrow$ & $\uparrow$ & $\uparrow$ & $\uparrow$ & $\uparrow$ & $\uparrow$ & & \\
\hline Surface Flow & & $\begin{array}{l}\text { Elizabeth } \\
\text { Highway }\end{array}$ & 1968 & 2017 & 50 & & & & & $\uparrow$ & $\uparrow$ & $\uparrow$ & & $\uparrow$ & $\uparrow$ & & \\
\hline Precipitation & Inside & & 1968 & 2013 & 46 & & & & & & & & & & & & \\
\hline Rainfall & Inside & Toronto & 1968 & 2013 & 46 & & & & & & & & & & & & \\
\hline Snowfall & Inside & $\begin{array}{c}\text { Lester Pearson } \\
\text { International }\end{array}$ & 1968 & 2013 & 46 & & & & & * & * & * & * & * & * & & $\downarrow$ \\
\hline Max Temp. & Inside & Airport & 1968 & 2013 & 46 & $\uparrow$ & & & & & $\uparrow$ & & & $\uparrow$ & & $\uparrow$ & $\uparrow$ \\
\hline Min Temp. & Inside & & 1968 & 2013 & 46 & $\uparrow$ & & $\uparrow$ & $\uparrow$ & $\uparrow$ & $\uparrow$ & $\uparrow$ & $\uparrow$ & $\uparrow$ & $\uparrow$ & $\uparrow$ & $\uparrow$ \\
\hline \multicolumn{18}{|c|}{ Watershed: Don river at Todmorden, ID: $02 \mathrm{HC} 024$} \\
\hline Streamflow & & & 1962 & 2017 & 56 & $\uparrow$ & & & $\uparrow$ & $\uparrow$ & $\uparrow$ & $\uparrow$ & $\uparrow$ & $\uparrow$ & $\uparrow$ & $\uparrow$ & $\uparrow$ \\
\hline Baseflow & & $\begin{array}{l}\text { Don river at } \\
\text { Todmorden }\end{array}$ & 1962 & 2017 & 56 & $\uparrow$ & & & $\uparrow$ & $\uparrow$ & & & $\uparrow$ & $\uparrow$ & & $\uparrow$ & \\
\hline Surface Flow & & & 1962 & 2017 & 56 & & & $\downarrow$ & $\downarrow$ & & & & & & & & $\downarrow$ \\
\hline Precipitation & Inside & & 1962 & 2013 & 52 & & & & & & $\uparrow$ & & & & & & \\
\hline Rainfall & Inside & & 1962 & 2013 & 52 & & & & & & $\uparrow$ & & & & & & \\
\hline Snowfall & Inside & Richmond Hill & 1962 & 2013 & 52 & & & & & * & * & * & * & * & * & & \\
\hline Max Temp. & Inside & & 1962 & 2013 & 52 & $\uparrow$ & & $\uparrow$ & $\uparrow$ & & & $\uparrow$ & $\uparrow$ & $\uparrow$ & & & $\uparrow$ \\
\hline Min Temp. & Inside & & 1962 & 2013 & 52 & $\uparrow$ & & & $\uparrow$ & $\uparrow$ & $\uparrow$ & $\uparrow$ & $\uparrow$ & $\uparrow$ & & & $\uparrow$ \\
\hline
\end{tabular}

The upward arrow $(\uparrow)$ signifies a significant increasing trend, and the downward arrow $(\downarrow)$ signifies a significant decreasing trend $(\alpha=0.05)$. The asterisk symbol $\left.{ }^{\star}\right)$ signifies presence of considerable number of "zero" values in the data that did not permit us to perform the trend analysis for the specified month.

for all the months. It was found that, in general, the minimum and maximum temperature was found to increase in the summer months for this watershed. It should be noted that although this station is not a part of the Reference Hydrometric Basin Network (RHBN), it is assumed that there is no significant change in the land use of this watershed over a period of 50 years (1966-2016); this is evident from the land use maps of the watershed (Figure 1).

Significant trends in hydrometric and climatic parameters were observed for the watershed of Nith River near Canning. There are two climate stations (Glen Allan and Roseville), and one RHBN hydrometric station within the watershed. The results suggest that since 1973, for a common period of time of approximately 45 years, the watershed witnessed a significant decrease in the rainfall for the month of March. The decreasing trend in the surface runoff for this month can also be attributed to this reason. Also, the minimum temperatures for the 


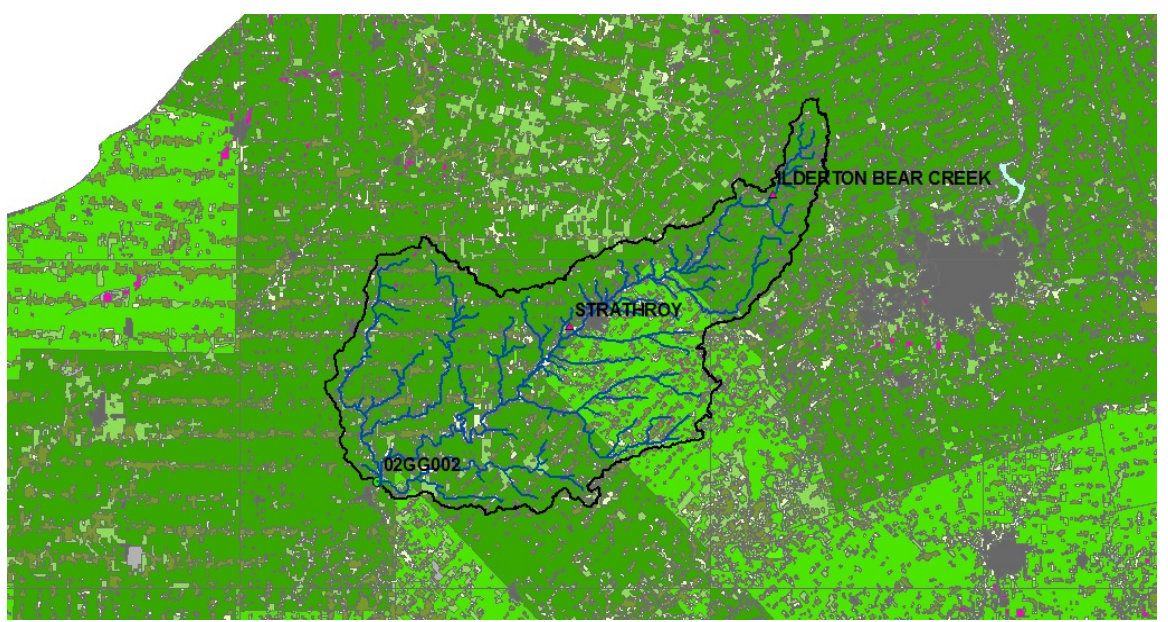

(a)

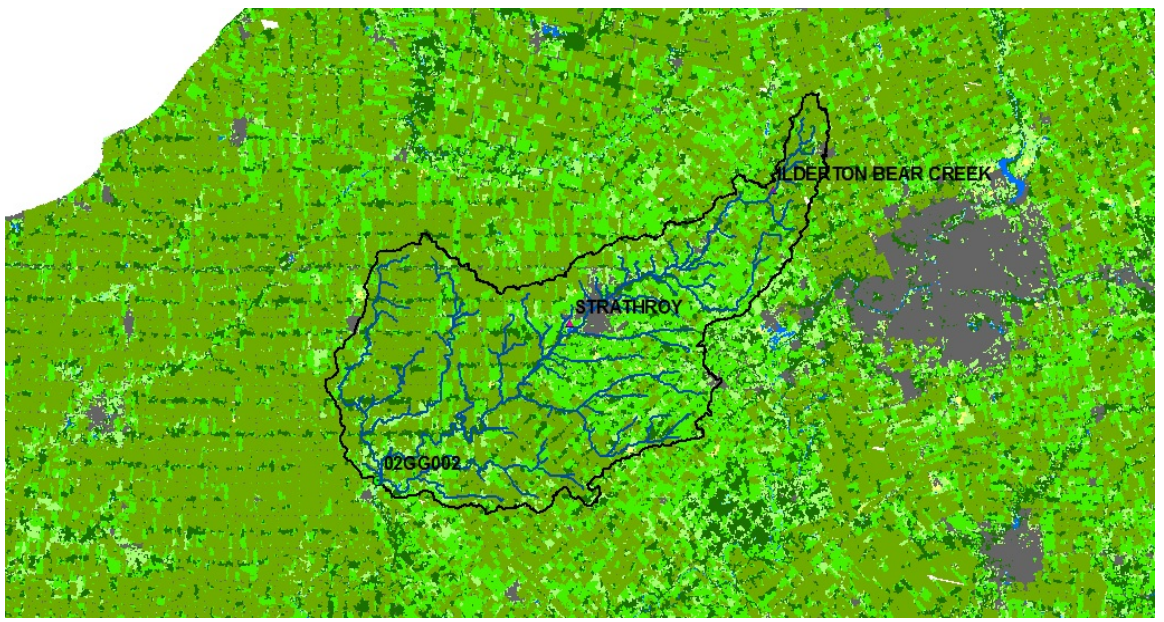

(b)

Figure 1. Landuse maps for the Sydenham river watershed near Alvinston for the years 1966 (a) and 2016 (b). The grey color represents the urbanized area, and the green colors indicate the rural and forest areas.

summer months and the month of December were found to increase. Consequently, the surface runoff and baseflow during January and July exhibited significant upward trends.

Significant trends for the watershed of Sydenham river near Owen Sound are also presented in Table 2 . Since 1968, for a period of approximately 45 years, significant increasing trends in the baseflow and streamflow for the month of January are observed. The two climate stations selected for this watershed (Chatsworth and Owen Sound MOE) exhibited a similar pattern of increase in the monthly mean minimum temperatures for summer and winter months. Results from the Owen Sound MOE station also revealed an increase in the mean maximum temperatures during the summer (Jun and August). Interestingly, the average rainfall was found to decrease for the month of August and increase during October. For this watershed, the average monthly streamflow for the period of 2008 to 2017 is more than the previous decade for most of the months. 
No climate station was present within the watershed of the Skootamatta river near Actinolite. Based on the results of the trend analysis for the period of 1958 to 2017, there are significant upward trends in the average monthly streamflow for the months of December, January, and February which are mainly due to the increasing trend in the baseflow. However, there is a decrease in the average monthly baseflow and streamflow for the month of May. In this watershed, the average of monthly streamflow for the period of 2008 to 2017 is more than the average of monthly streamflow for the period of 1998 to 2007 for almost all of the months.

The common period selected for trend analysis of parameters for the watershed of Black River near Washago was 49 years (1958-2006). The watershed exhibited a significant increase in the streamflow and baseflow for the winter months of January, February, and March, as well as an increase in the surface flow for the month of January. This can be attributed to the increasing trends for the mean maximum temperatures for the winter months of December, February, and March. A significant increase in the rainfall for the month of May was observed, but this did not translate to an increase in the observed hydrometric parameters' values. This can be due to the increase in mean monthly maximum and minimum temperatures for the summer months (June, July and August), which can have an effect on the total amount of water attributed to evapotranspiration. The decadal average of monthly streamflow for this watershed for the period of 2008 to 2017 is more than that of the decade before, for all of the months.

The data selected for trend analysis for the watershed of Jock River near Richmond spanned from the year 1968 to 2017 (50 years). The streamflow and surface flow for the watershed were found to increase over the years for the months of January and June. For the summer months of July and August, the baseflow was also found to increase. This may have caused an increase in the streamflow in the month of July for the watershed. Mean monthly precipitation was found to decrease for the months of March and November. Amount of snowfall received by the watershed in November significantly decreased over the years. This may be attributed to an increase in mean maximum monthly temperatures for September and November. The 02LA007 station corresponding to this watershed is not a part of the RHBN stations, however, the land use for this watershed did not change significantly over the past 50 years. This is also evident from the land use maps for the watershed for years 1966 and 2016 (Figure 2).

Based on the availability of data, a period of 60 years (1958-2017) was chosen to perform the trend analysis for the watershed of North Magnetawan river near Burk's Falls; no reliable climatic data was available for this watershed. Streamflow and baseflow were found to significantly increase for the winter months of January, February and March, whereas the surface flow also increased for December, January and February. The results are consistent with the baseflow trends observed for other watersheds in this study. The decadal average of monthly 


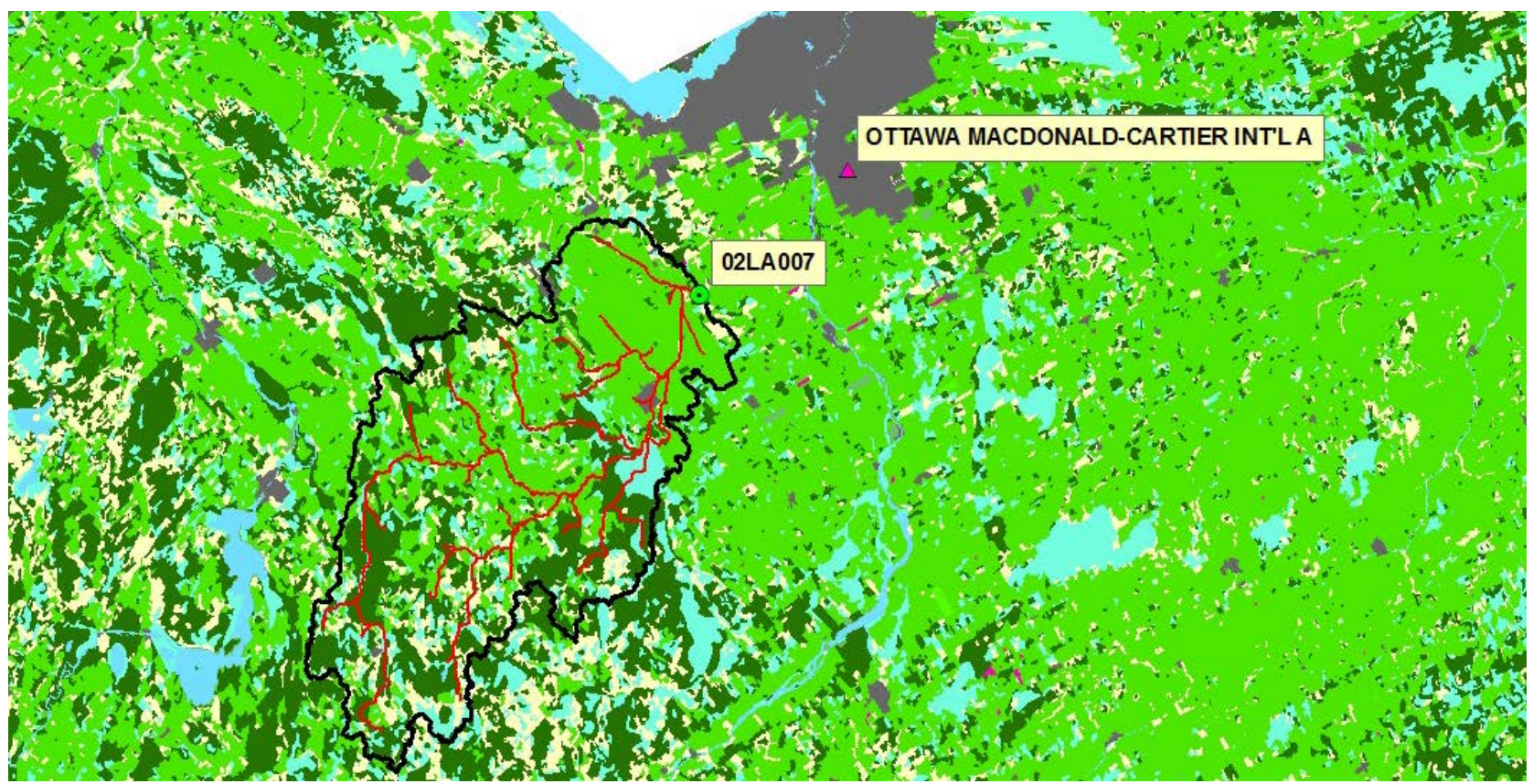

(a)

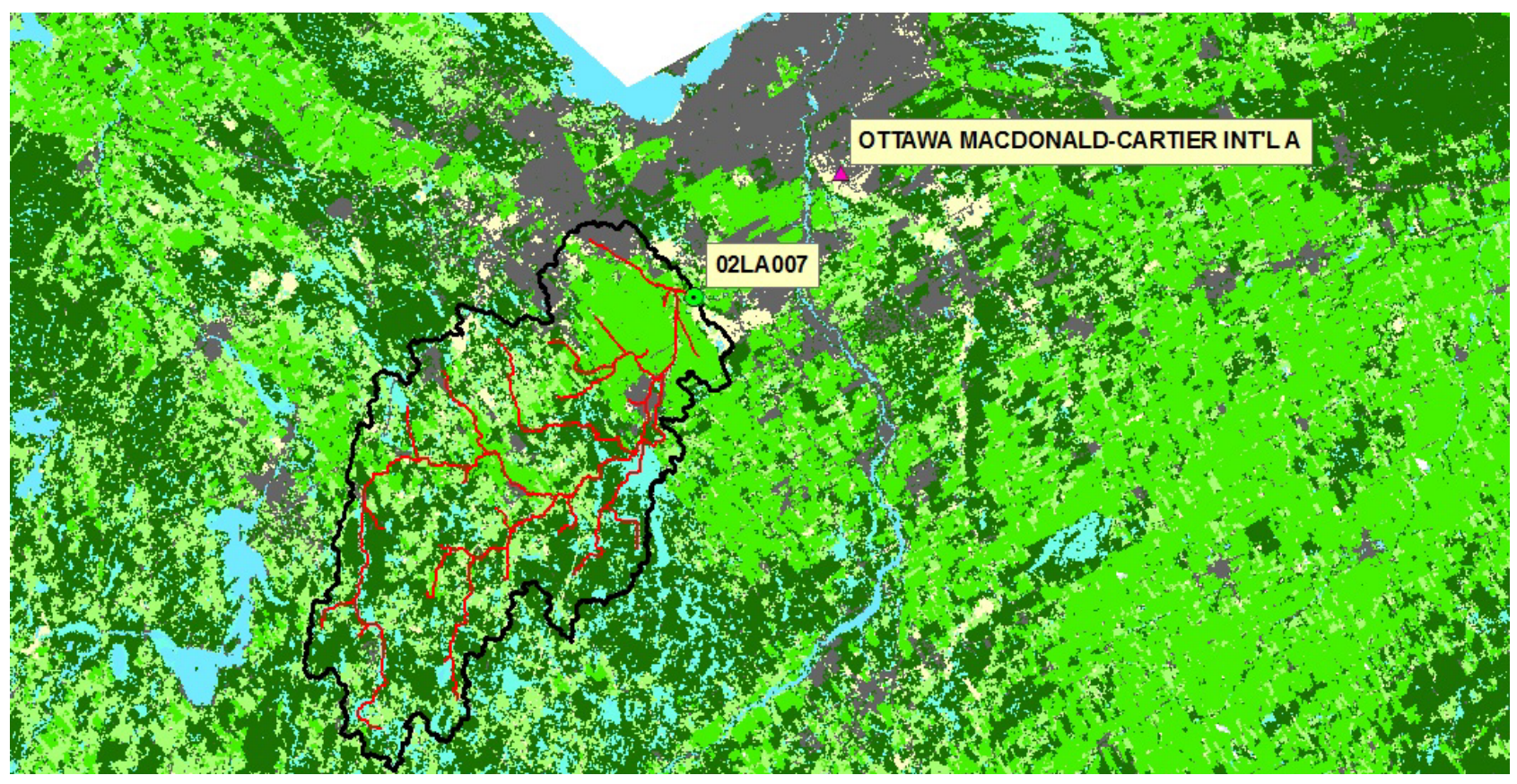

(b)

Figure 2. Landuse maps for the Jock river watershed near Richmond for the years 1966 (a) and 2016 (b). The grey color represents the urbanized area, and the green colors indicate the rural and forest areas.

streamflow of the North Magnetawan river near Burk's Falls, from 2008 to 2017 is more than the average of monthly streamflow for the period of 1998 to 2007 for all of the months except for the month of October. Also, like all of the previous watersheds, the month of April has the highest decadal average of monthly streamflow.

A total of 50 years of data (1968-2017) was used for performing trend analysis 
for the watershed of Goulais river near Searchmont. Unlike other watersheds, data from the hydrometric station 02BF002 suggested no increasing trend for the baseflow for this watershed during the winter months. On the contrary, the mean monthly baseflow was found to decrease during the summer (Jun-Aug). Unfortunately, climate data was not available for this watershed, for the selected duration. The decadal average of monthly streamflow for the period of 2008 to 2017 is more than the average of monthly streamflow for the period of 1998 to 2007 for all of the months except for the month of April.

The mean monthly surface flow for the watershed of Neebing River near Thunder Bay was found to increase during the month of July and decrease significantly for the month of December. For the same watershed, the minimum temperature for the month of October was found to decrease over the period of past 36 years, and consequently the amount of mean monthly snowfall ws found to increase for the same month. This was not in accordance with the results for other watersheds considered for this study. A duration of 36 years (1958-1993) was chosen to perform the trend analysis. The decadal average monthly streamflow for the period of 2008 to 2017 is more than the average of monthly streamflow observed between 1998 to 2007 for all of the months except for the months of April and October.

The average monthly streamflow and baseflow were found to decrease during the fall months (Aug-Oct) for the watershed of Missinaibi river at Mattice across a period of 1958 to 2017. The average monthly surface flow was found to significantly increase in March and decrease during the months of May of September. The observed surface runoff values are mostly "Zero" during the winters (Dec-Mar) due to icy conditions. No climate data was available for the watershed for the given time period. The decadal average monthly streamflow for the period of 2008 to 2017 is more than the average of monthly streamflow for the period of 1998 to 2007 for all of the months except for the months of April and October.

Trend analysis of various parameters considered across 38 years (1958-1995) for the watershed of Nagagami river at Highway No.11 revealed that the average monthly streamflow and baseflow decreased during the month of June. Also, a decreasing trend in the monthly average maximum temperature for October was observed. Unlike the other watersheds, the decadal average monthly streamflow for the period of 2008 to 2017 was not found to be higher than the average monthly streamflow of the decade before that. Also, as compared to other watersheds considered within the study, the decadal average monthly streamflow was found to be higher in the month of May; the month of April had the highest decadal average monthly streamflow for other watersheds.

The mean monthly streamflow and baseflow were found to increase during the winter months (Nov-Feb) for the watershed of North French River near the mouth from year 1968 to 2017 (50 years). The Moosonee UA climate stations provided climatic data for this duration, with three years of missing data. The surface flow within the watershed was also found to increase during the months 
of March and November. Except for the spring season, the mean minimum monthly temperatures were found to increase for the whole year. The mean maximum monthly temperatures for the months of January, July and September were also found to increase within the watershed. Except for February, no other months witnessed an increase in mean monthly precipitation.

The northernmost watershed considered in the present study is the watershed of Pipestone river at Karl Lake; data collected across 49 years (1968-2016) was considered for the trend analysis. No significant trends in average monthly streamflow or baseflow were observed for this watershed. No climate station with available data was situated near this watershed. The RHBN station 04DA001 which is located on this watershed has a backwater problem due to ice conditions in winter months. The month of May has the highest decadal average monthly streamflow for this watershed.

\subsection{Urban Watersheds}

Table 3 presents the results of the trend analysis for the selected urban watersheds. The area of watershed corresponding to the station $02 \mathrm{HC} 030$, which is located on Etobicoke Creek below Queen Elizabeth Highway is approximately $205 \mathrm{~km}^{2}$. The watershed has developed considerably during the past 50 years and most of the agricultural lands have turned into urban area (Figure 3). Figure 4 shows the decadal average monthly streamflow for the urban watersheds; even with the huge amount of land use change in the past decades, the Etobicoke Creek station still receives unregulated flow (Environment and Climate Change Canada, 2012) and thus, it can be used as a measure to study the effects of urbanization on hydrometric and climatic parameters. No significant increasing or decreasing trends in the average monthly precipitation for the past fifty years (1968 to 2017) was observed within the watershed (Figure 4(a)). However, the average monthly minimum temperature increased significantly for almost every month. Also, the streamflow, baseflow and the surface runoff seemed to increase during the months of May to October. One of the possible reasons for this significant increase in the surface runoff during these months is the effect of urbanization, leading to reduced infiltration rate. In order to investigate the significant increase in baseflow, without an increase in precipitation, snowfall, and rainfall for the watershed, baseflow separation from the surface runoff was studied using the one-parameter filter method. This technique separates the slow flow from the quick flow using the filter method. The major components of the slow flow in urban watersheds are considered to be: 1) the classical baseflow from groundwater inflow to the stream, and 2) the drainage flow from the detention ponds that are created for storm-water management purposes (Liu et al., 2013).

The Greater Toronto Area (GTA) has developed rapidly during the last 50 years, and a complex network of storm-water management ponds and canals have been designed to control flooding in the newly developed urban area. Before 


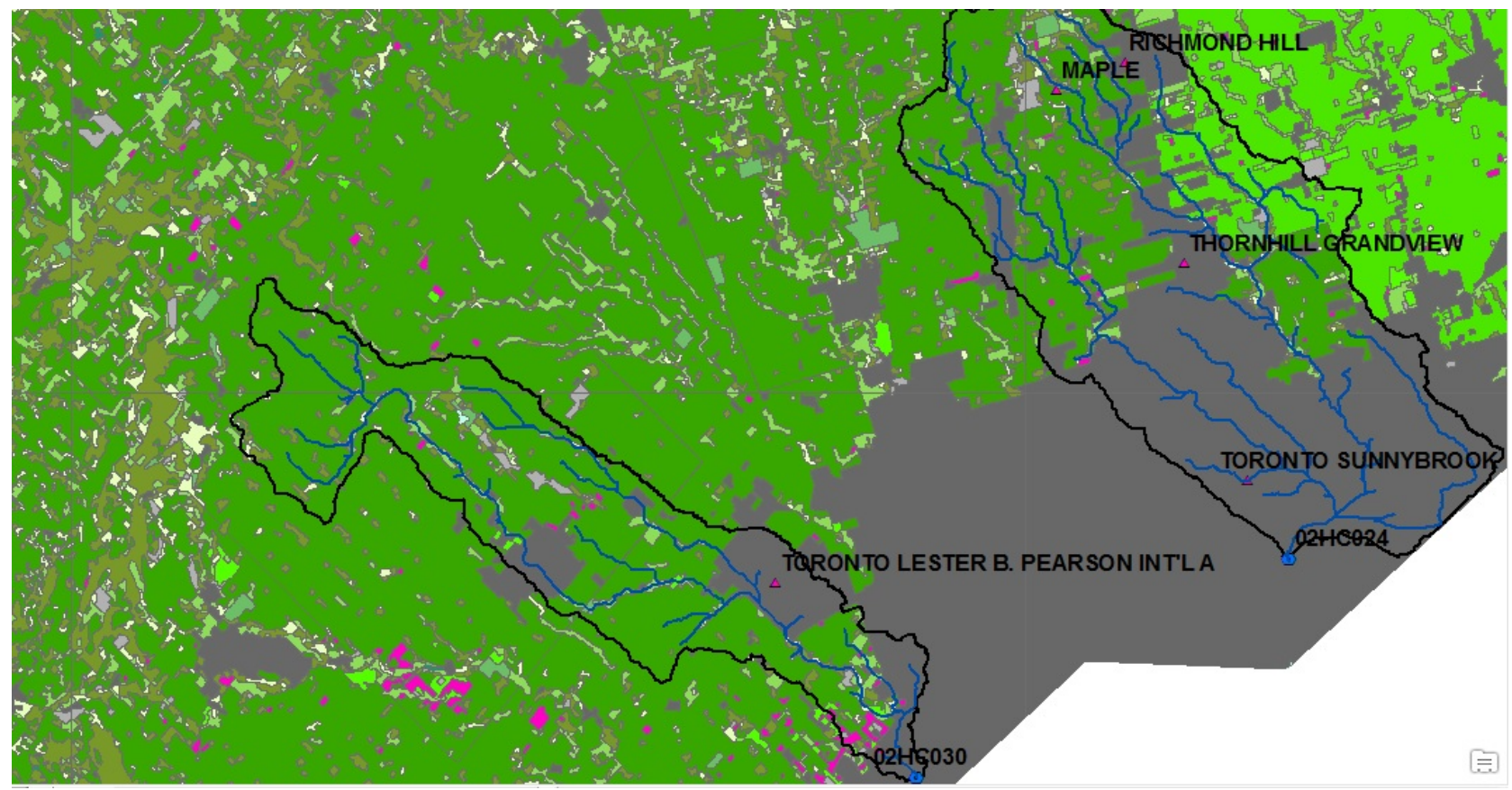

(a)

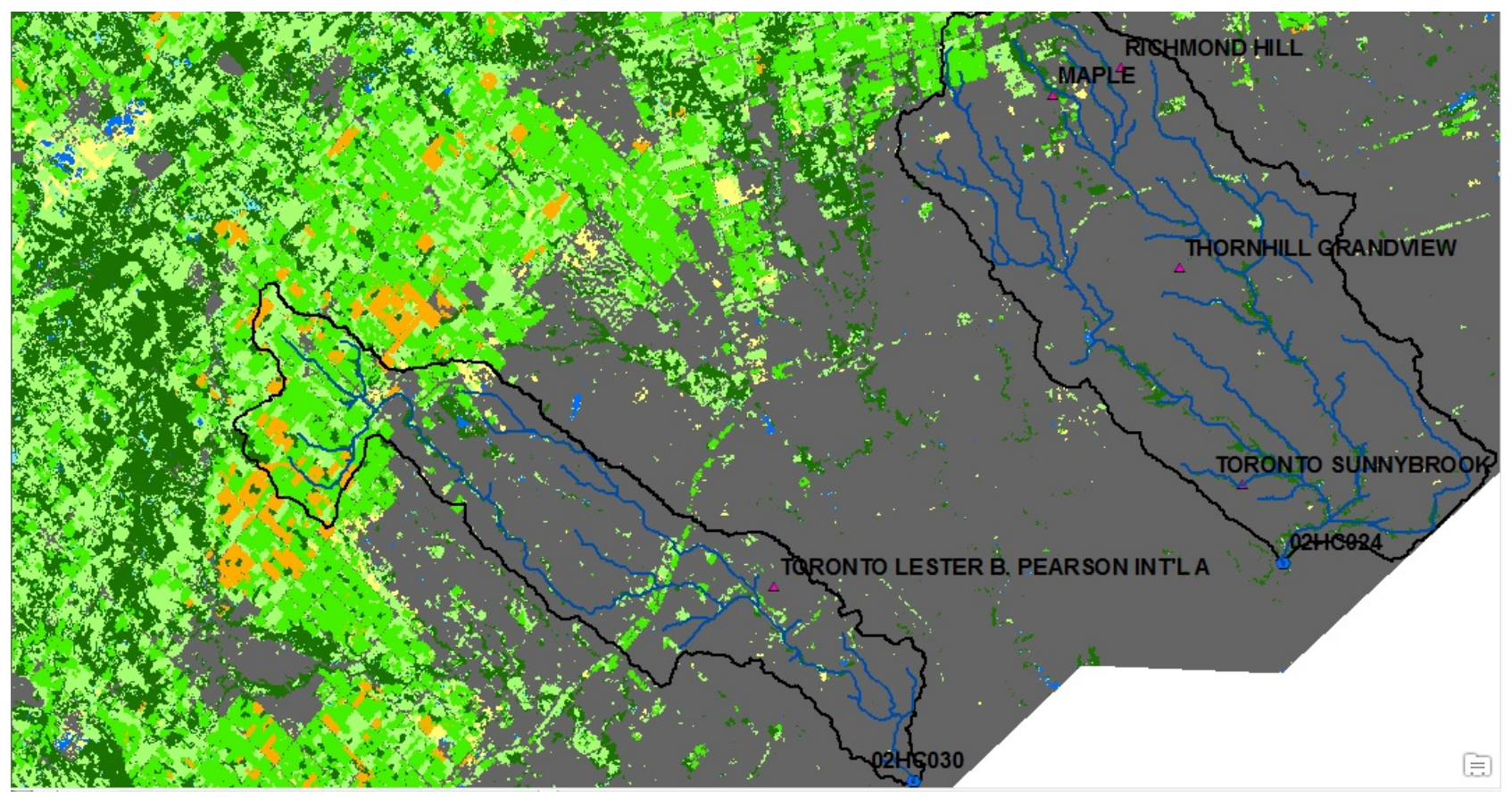

(b)

Figure 3. Landuse maps for the urban watersheds at the Etobicoke Creek below Queen Elizabeth Highway and Don river at Todmorden for the years 1966 (a) and 2016 (b). The grey color represents the urbanized area, and the green colors indicate the rural and forest areas.

urbanization, the infiltrated water was eventually discharged into the streams, lakes, or neighboring watersheds. But, after development as the permeable layer decreased at the surface, larger amounts of water that was supposed to infiltrate, stayed at the surface. To control flooding, many storm-water management ponds 


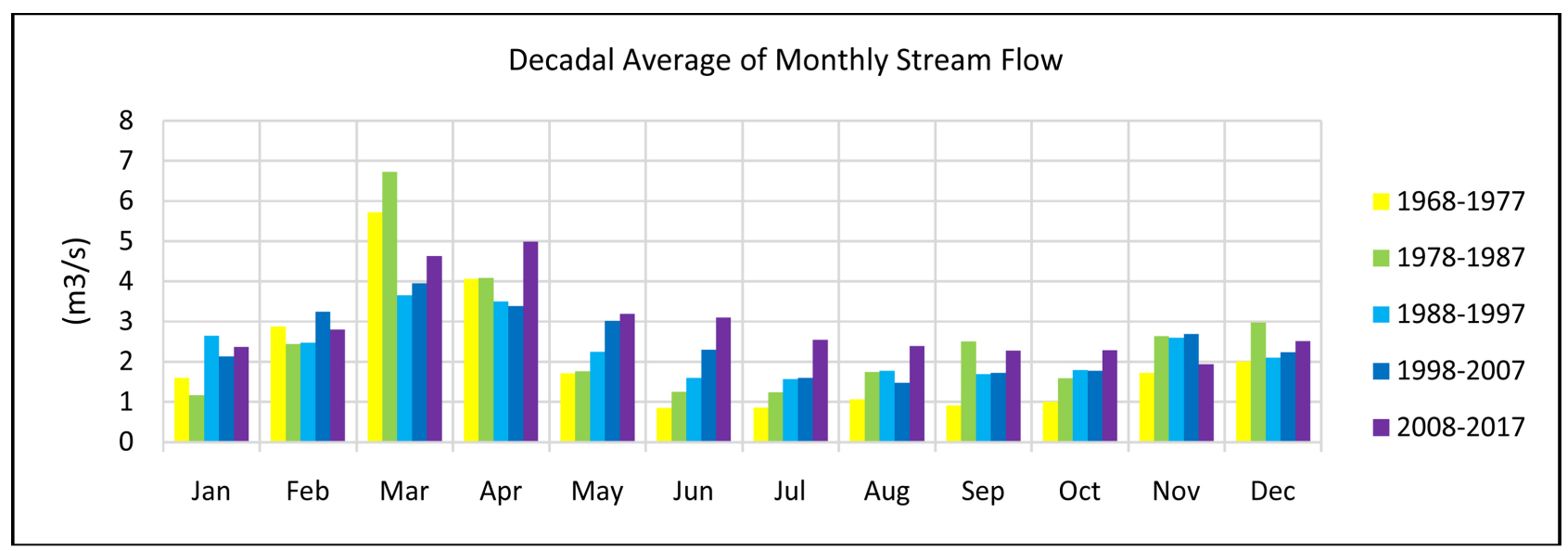

(a)

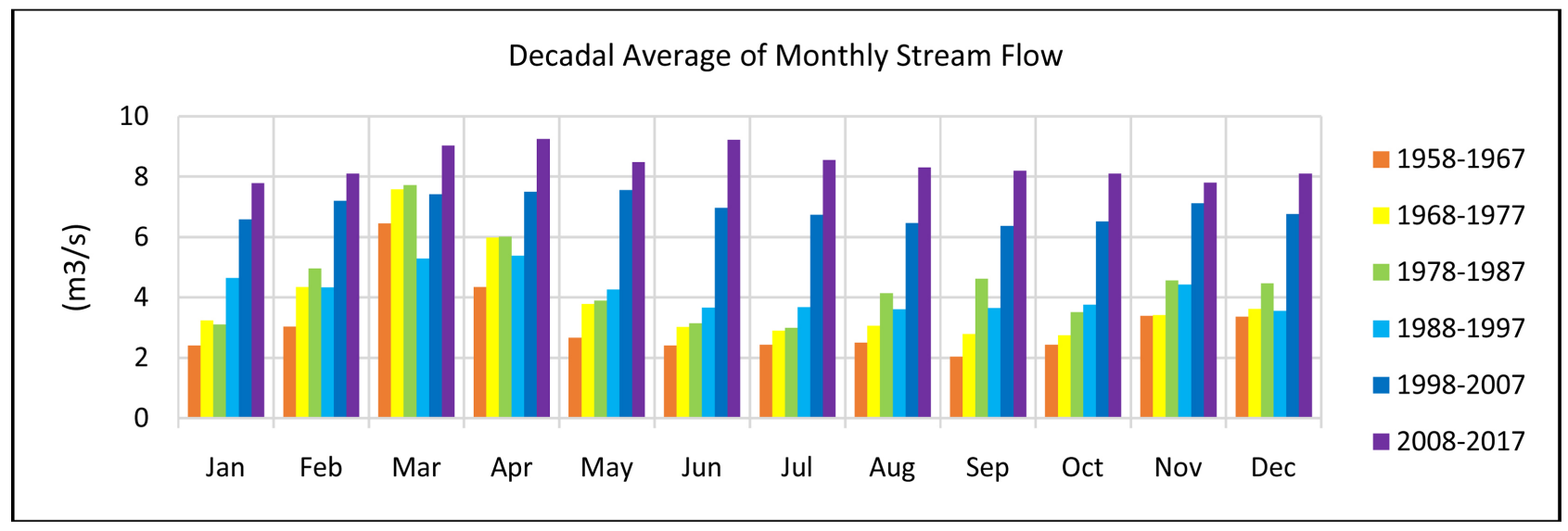

(b)

Figure 4. Decadal average monthly streamflow for the Etobicoke Creek watershed below Queen Elizabeth Highway (a), and The Don river watershed at Todmorden (b).

have been designed, thus changing the shape of the hydrograph in a way that the slow flow increases.

The Don River at Todmorden watershed is $319 \mathrm{~km}^{2}$ in size and its station $02 \mathrm{HC} 024$ receives regulated flow from the river. As the streamflow and the baseflow data have a significant lag 1 autocorrelation, the flow data from this station should not be treated like other stations in this study. However, the data from this watershed can still be used to check for similarities with other urban watersheds in the region. Based on the data collected from the Richmond Hill station over the period of 52 years (1962-2013), mean monthly precipitation was found to increase for the month of June, and did not vary significantly for the rest of the year. Similar to the results observed for the Etobicoke Creek watershed, increasing trends in streamflow and baseflow were observed. However, surface flow showed a decreasing trend for the months of March, April and December. Figure 4(b) shows the decadal average of the monthly streamflow of the Don River at Todmorden; with passing decades, the average monthly streamflow was found to increase significantly. 
Table 4. Significant trends in streamflow, baseflow, and surface runoff for rural watersheds located in southern Ontario.

\begin{tabular}{|c|c|c|c|c|c|c|c|c|c|c|c|c|c|c|c|c|}
\hline \multirow[b]{2}{*}{ Station Name } & \multirow[b]{2}{*}{ ID } & \multicolumn{7}{|c|}{ Time period of data used } & \multicolumn{8}{|c|}{ Month of the year } \\
\hline & & Start & End & $\begin{array}{c}\text { Duration } \\
\text { (years) }\end{array}$ & Jan & Feb & Mar & Apr & May & Jun & Jul & Aug & Sep & Oct & Nov & Dec \\
\hline \multicolumn{17}{|c|}{ Streamflow } \\
\hline $\begin{array}{l}\text { Sydenham river } \\
\text { near alvinston }\end{array}$ & 02GG002 & 1968 & 2017 & 50 & & & & & & & & & & & & \\
\hline Nith river near canning & 02GA010 & 1968 & 2017 & 50 & $\uparrow$ & & & & & $\uparrow$ & $\uparrow$ & & & & & \\
\hline $\begin{array}{c}\text { Sydenham river near } \\
\text { owen sound }\end{array}$ & $02 \mathrm{FB} 007$ & 1968 & 2017 & 50 & $\uparrow$ & & & & & & & & & & & \\
\hline $\begin{array}{l}\text { Skootamatta river } \\
\text { near actinolite }\end{array}$ & 02HL004 & 1968 & 2017 & 50 & $\uparrow$ & & & $\downarrow$ & & & & & & $\uparrow$ & & \\
\hline Black river near washago & $02 \mathrm{EC} 002$ & 1968 & 2017 & 50 & $\uparrow$ & & & & & & & & & & & \\
\hline Jock river near richmond & 02LA007 & 1970 & 2017 & 48 & $\uparrow$ & & & & & $\uparrow$ & $\uparrow$ & & & & & \\
\hline $\begin{array}{l}\text { North magnetawan } \\
\text { river near burk's falls }\end{array}$ & 02EA005 & 1968 & 2017 & 50 & $\uparrow$ & $\uparrow$ & & & & & & & & & & $\uparrow$ \\
\hline
\end{tabular}

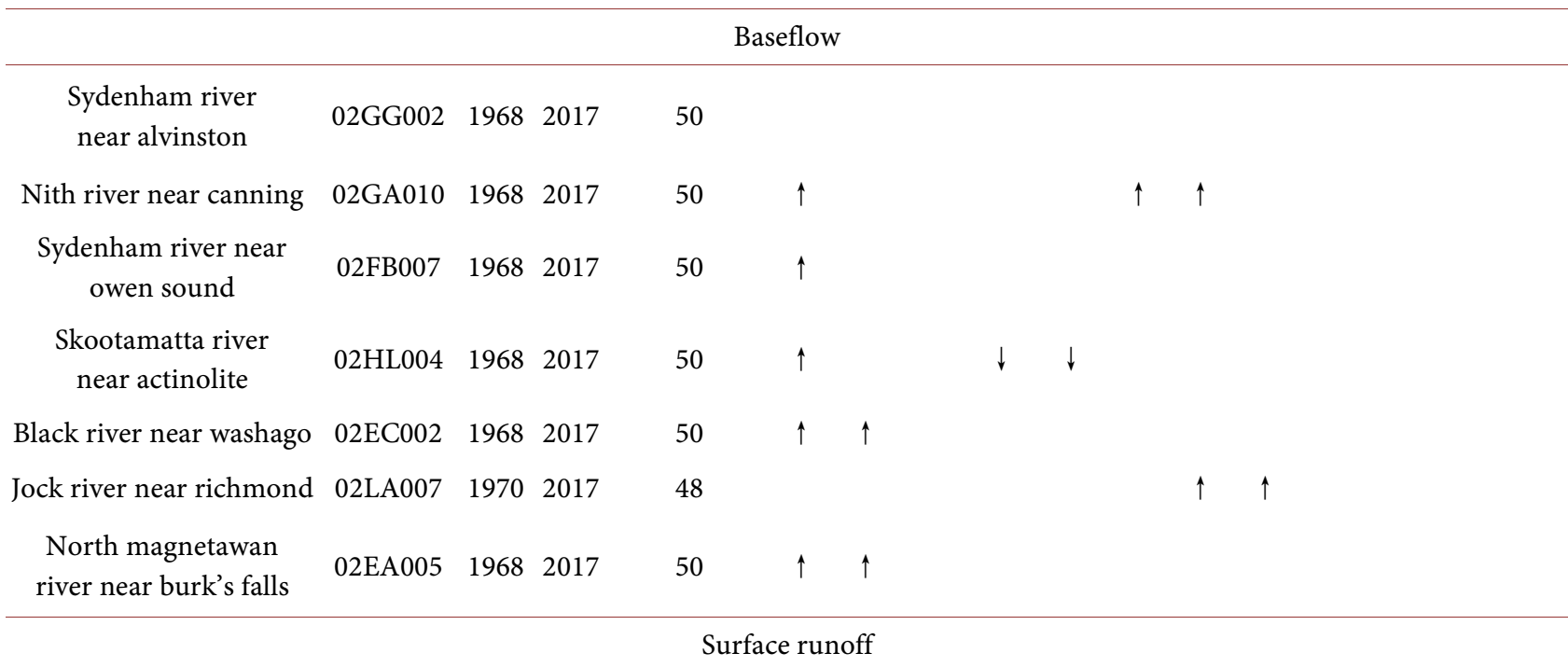

\begin{tabular}{|c|c|c|c|c|c|c|c|}
\hline $\begin{array}{l}\text { Sydenham river } \\
\text { near alvinston }\end{array}$ & 02GG002 & 1968 & 2017 & 50 & & & \\
\hline Nith river near canning & 02GA010 & 1968 & 2017 & 50 & $\uparrow$ & $\uparrow$ & \\
\hline $\begin{array}{c}\text { Sydenham river near } \\
\text { owen sound }\end{array}$ & 02FB007 & 1968 & 2017 & 50 & & & \\
\hline $\begin{array}{c}\text { Skootamatta river near } \\
\text { actinolite }\end{array}$ & 02HL004 & 1968 & 2017 & 50 & $\uparrow$ & $\uparrow$ & $\uparrow$ \\
\hline Black river near washago & $02 \mathrm{EC} 002$ & 1968 & 2017 & 50 & $\uparrow$ & $\uparrow$ & \\
\hline Jock river near richmond & 02LA007 & 1970 & 2017 & 48 & $\uparrow$ & $\uparrow$ & \\
\hline $\begin{array}{l}\text { North magnetawan river } \\
\text { near burk's falls }\end{array}$ & 02EA005 & 1968 & 2017 & 50 & $\uparrow$ & & \\
\hline
\end{tabular}

The upward arrow $(\uparrow)$ signifies a significant increasing trend, and the downward arrow $(\downarrow)$ signifies a significant decreasing trend $(\alpha=0.05)$. 
Table 5. Significant trends in streamflow, baseflow, and surface runoff for rural watersheds located in northern Ontario.

\begin{tabular}{|c|c|c|c|c|c|c|c|c|c|c|c|c|c|c|c|c|}
\hline \multirow[b]{2}{*}{ Station Name } & \multirow[b]{2}{*}{ ID } & \multicolumn{7}{|c|}{ Time period of data used } & \multicolumn{8}{|c|}{ Month of the year } \\
\hline & & Start & End & $\begin{array}{l}\text { Duration } \\
\text { (years) }\end{array}$ & Jan & Feb & Mar & Apr & May & Jun & Jul & Aug & Sep & Oct & Nov & Dec \\
\hline \multicolumn{17}{|c|}{ Streamflow } \\
\hline $\begin{array}{c}\text { Goulais river } \\
\text { near searchmont }\end{array}$ & 02BF002 & 1968 & 2017 & 50 & & & & & & $\downarrow$ & & & & & & \\
\hline $\begin{array}{c}\text { Neebing river } \\
\text { near thunder bay }\end{array}$ & $02 \mathrm{AB} 008$ & 1968 & 2016 & 49 & & & & $\downarrow$ & & & & & & $\downarrow$ & & \\
\hline Missinaibi river at mattice & 04LJ001 & 1968 & 2017 & 50 & & & & & & & & & & & & \\
\hline $\begin{array}{l}\text { Nagagami river at } \\
\text { highway no. } 11\end{array}$ & 04JC002 & 1968 & 2017 & 50 & & & & & & & & & & & & \\
\hline $\begin{array}{l}\text { North french river } \\
\text { near the mouth }\end{array}$ & 04MF001 & 1968 & 2017 & 50 & $\uparrow$ & $\uparrow$ & & & & & & & & & $\uparrow$ & $\uparrow$ \\
\hline Pipestone river at karl lake & 04DA001 & 1968 & 2016 & 49 & & & & & & & & & & & & \\
\hline \multicolumn{17}{|c|}{ Baseflow } \\
\hline $\begin{array}{c}\text { Goulais river } \\
\text { near searchmont }\end{array}$ & 02BF002 & 1968 & 2017 & 50 & & & & & & $\downarrow$ & $\downarrow$ & $\downarrow$ & & & & \\
\hline $\begin{array}{c}\text { Neebing river } \\
\text { near thunder bay }\end{array}$ & $02 \mathrm{AB} 008$ & 1968 & 2016 & 49 & & & & $\downarrow$ & & & & & & $\downarrow$ & & \\
\hline Missinaibi river at mattice & 04LJ001 & 1968 & 2017 & 50 & & & & & & & & & & & & \\
\hline $\begin{array}{l}\text { Nagagami river } \\
\text { at highway no. } 11\end{array}$ & 04JC002 & 1968 & 2017 & 50 & & & & & & & & & & & & \\
\hline $\begin{array}{l}\text { North french river } \\
\text { near the mouth }\end{array}$ & 04MF001 & 1968 & 2017 & 50 & $\uparrow$ & $\uparrow$ & & $\uparrow$ & & & & & & & $\uparrow$ & $\uparrow$ \\
\hline Pipestone river at karl lake & 04DA001 & 1968 & 2016 & 49 & & & & & & & & & & & & \\
\hline \multicolumn{17}{|c|}{ Surface runoff } \\
\hline $\begin{array}{c}\text { Goulais river } \\
\text { near searchmont }\end{array}$ & 02BF002 & 1968 & 2017 & 50 & & & & & & $\downarrow$ & & & & & & $\uparrow$ \\
\hline $\begin{array}{l}\text { Neebing river near } \\
\text { thunder bay }\end{array}$ & 02AB008 & 1968 & 2016 & 49 & * & & & $\downarrow$ & & & & & & & & \\
\hline Missinaibi river at mattice & 04LJ001 & 1968 & 2017 & 50 & * & * & $\uparrow$ & & & & & & & & & $\uparrow$ \\
\hline $\begin{array}{l}\text { Nagagami river } \\
\text { at highway no. } 11\end{array}$ & 04JC002 & 1968 & 2017 & 50 & * & * & $\uparrow$ & & & & & & & & & $\uparrow$ \\
\hline $\begin{array}{l}\text { North french river } \\
\text { near the mouth }\end{array}$ & 04MF001 & 1968 & 2017 & 50 & * & * & $\uparrow$ & & & & & & & & $\uparrow$ & * \\
\hline Pipestone river at karl lake & 04DA001 & 1968 & 2016 & 49 & * & * & & & & & & & & & & * \\
\hline
\end{tabular}

The upward arrow $(\uparrow)$ signifies a significant increasing trend, and the downward arrow $(\downarrow)$ signifies a significant decreasing trend $(\alpha=0.05)$. The asterisk symbol $\left.{ }^{\star}\right)$ signifies presence of considerable number of "zero" values in the data that did not permit us to perform the trend analysis for the specified month.

\section{Discussion}

\subsection{Watersheds in Southern Ontario}

As per the results of the trend analysis for each watershed, some similarities in 
the trends of climatic and hydrometric parameters can be found for watersheds within a given region of the province. For investigating these similarities, all watersheds were sorted according to their latitude and land use. Significant trends in the streamflow, baseflow, and surface runoff, were then calculated for a common period of time (1968-2017) for all of the watersheds. Table 4 shows the significant streamflow trends for rural watersheds located in the southern region of the province (below 45 degrees latitude, north). According to the trend analysis, all of the RHBN rural watersheds exhibited a significant increase in the streamflow during the month of January. Correspondingly, the baseflow for these watersheds was also found to increase during the month of January, and for some cases in February. The baseflow of all of the rural watersheds is significantly increasing in the month of January and for some cases in February. Since the surface runoff has can be impacted by changes in climatic parameters more than baseflow, the pattern of significant trends of surface runoff in this region is slightly different than the pattern of significant baseflow for the same period. Surface runoff was mostly found to increase during the month of January.

\subsection{Watersheds in Northern Ontario}

Table 5 shows the significant trends in the streamflow, baseflow and surface runoff of the rural watersheds which are located north of 45 degrees of latitude for the period of 1968 to 2017. Except for the North French River watershed, either there is no significant change in the streamflow and baseflow, or a decreasing trend is observed. The results are not similar to the ones obtained for the southern watersheds, highlighting the variations in the climate change effects based on the geographic locations within the province. In case of surface runoff, the asterisk symbol $\left({ }^{*}\right)$ represent "zero" values in the time-series; in some of the watersheds in the northern regions of Ontario, the surface gets frozen in the winter months causing no flow. However, a positive trend is observed for the months of March and December for most of the selected watersheds in northern Ontario. The different behavior of the North French River watershed as compared to other northern watersheds can be attributed to the increase in mean minimum monthly temperatures for most of the months, as shown in Table 2. Based on the discussion of the results, an urgent need for local authorities and decision makers to propose and develop new water management strategies emerges. These strategies should be designed by taking into account the regional variations of the impact of climate change on hydrology of watersheds within Ontario.

\section{Conclusion}

Significant upward trends were observed for total streamflow, baseflow and surface runoff during the winter and summer months in watersheds situated in southern Ontario. This was mainly attributed to the increasing trends for the monthly average minimum temperatures for this time period. The observed in- 
creasing trend in the minimum and maximum temperatures for the winter months can speed up the process of snowmelt and alter the hydrological processes for these watersheds. Unlike the southern Ontario watersheds, very few instances of significant changes in the mean monthly temperatures (minimum and maximum) were observed for the watersheds located in northern part of Ontario; in some cases, decreasing trends were also observed. Similarly, very few instances of significant decrease in the baseflow during summer months were also observed for some of the watersheds in the north (except North French River watershed). The results of this study also indicate that in the selected urban watersheds, the average monthly minimum and maximum temperatures are increasing for almost all of the months. Also, the streamflow, baseflow, and surface runoff were found to increase for the Etobicoke watershed during the summer and fall season, possibly due to rapid urbanization, causing reduced infiltration rate. According to the findings of this study, local and regional decision-makers must soon propose and adopt new water management strategies, particularly in light of changing climate and land use patterns. These methods should be developed with geographic differences in the effects of climate change on the hydrology of Ontario's watersheds in mind.

\section{Acknowledgements}

This study was supported by Natural Sciences and Engineering Research Council of Canada (NSERC).

\section{Conflicts of Interest}

The authors declare no conflicts of interest regarding the publication of this paper.

\section{References}

ACIA (Arctic Climate Impact Assessment) (2005). Arctic Climate Impact Assessment. Cambridge University Press.

AMAP-SWIPA (Arctic Monitoring and Assessment Programme-Snow, Water, Ice and Permafrost in the Arctic) (2011). SWIPA 2011 Executive Summary: Snow, Water, Ice and Permafrost in the Arctic.

Arnold, J., Allen, P., Muttiah, R., \& Bernhardt, G. (1995). Automated Base Flow Separation and Recession Analysis Techniques. Groundwater, 33, 1010-1018. https://doi.org/10.1111/j.1745-6584.1995.tb00046.x

Barros, V., Field, C., Dokke, D., Mastrandrea, M., Mach, K., Bilir, T. et al. (2014). Climate change 2014: Impacts, Adaptation, and Vulnerability-Part B: Regional Aspects-Contribution of Working Group II to the Fifth Assessment Report (AR5) of the Intergovernmental Panel on Climate Change (IPCC). Cambridge University Press. https://doi.org/10.1017/CBO9781107415386

Burn, D. H., \& Elnur, M. A. H. (2002). Detection of Hydrologic Trends and Variability. Journal of Hydrology, 255, 107-122. https://doi.org/10.1016/S0022-1694(01)00514-5

Church, J. A., Clark, P. U., Cazenave, A., Gregory, J. M., Jevrejeva, S., Levermann, A. et al. 
(2013). Sea Level Change. In T. F. Stocker, D. Qin, G.-K. Plattner et al. (Eds.), Climate Change 2013: The Physical Science Basis. Contribution of Working Group I to the Fifth Assessment Report of the Intergovernmental Panel on Climate Change (pp. 1137-1216). Cambridge University Press.

Cunderlik, J. M., \& Burn, D. H. (2004). Linkages between Regional Trends in Monthly Maximum Flows and Selected Climatic Variables. Journal of Hydrologic Engineering, 9, 246-256. https://doi.org/10.1061/(ASCE)1084-0699(2004)9:4(246)

Cunderlik, J. M., \& Ouarda, T. B. (2009). Trends in the Timing and Magnitude of Floods in Canada. Journal of Hydrology, 375, 471-480. https://doi.org/10.1016/j.jhydrol.2009.06.050

Dai, A. (2013). Increasing Drought under Global Warming in Observations and Models. Nature Climate Change, 3, 52-58. https://doi.org/10.1038/nclimate1633

Ehsanzadeh, E., \& Adamowski, K. (2007). Detection of Trends in Low Flows across Canada. Canadian Water Resources Journal, 32, 251-264. https://doi.org/10.4296/cwrj3204251

Environment and Climate Change Canada (2012). The Hydrometric Network. Environment and Climate Change Canada. http://www.ec.gc.ca/rhc-wsc/default.asp?lang\%20=Enandn=E228B6E8-1

Fazel-Rastgar, F. (2020). Seasonal Analysis of Atmospheric Changes in Hudson Bay during 1998-2018. American Journal of Climate Change, 9, 100-122. https://doi.org/10.4236/ajcc.2020.92008

Hamilton, L. C., \& Keim, B. D. (2009). Regional Variation in Perceptions about Climate Change. International Journal of Climatology: A Journal of the Royal Meteorological Society, 29, 2348-2352. https://doi.org/10.1002/joc.1930

Kendall, M. (1975). Rank Correlation Measures (p. 202, 15). Charles Griffin.

Liu, G., Schwartz, F., \& Kim, Y. (2013). Complex Baseflow in Urban Streams: An Example from Central Ohio, USA. Environmental Earth Sciences, 70, 3005-3014. https://doi.org/10.1007/s12665-013-2358-3

Lyne, V., \& Hollick, M. (1979). Stochastic Time-Variable Rainfall-Runoff Modeling. Paper Presented at the Institute of Engineers Australia National Conference. https://doi.org/10.1007/s12665-013-2358-3

Mann, H. B. (1945). Nonparametric Tests against Trend. Econometrica, 13, 245-259. https://doi.org/10.2307/1907187

McBean, E., \& Motiee, H. (2006). Assessment of Impacts of Climate Change on Water Resources? A Case Study of the Great Lakes of North America. Hydrology and Earth System Sciences Discussions, 3, 3183-3209. https://doi.org/10.5194/hessd-3-3183-2006

Nalley, D., Adamowski, J., \& Khalil, B. (2012). Using Discrete Wavelet Transforms to Analyze Trends in Streamflow and Precipitation in Quebec and Ontario (1954-2008). Journal of Hydrology, 475, 204-228. https://doi.org/10.1016/j.jhydrol.2012.09.049

Nathan, R. J., \& McMahon, T. A. (1990). Evaluation of Automated Techniques for Base Flow and Recession Analyses. Water Resources Research, 26, 1465-1473. https://doi.org/10.1029/WR026i007p01465

Peterson, T. C., Heim Jr., R. R., Hirsch, R., Kaiser, D. P., Brooks, H., Diffenbaugh, N. S. et al. (2013). Monitoring and Understanding Changes in Heat Waves, Cold Waves, Floods, and Droughts in the United States: State of Knowledge. Bulletin of the American Meteorological Society, 94, 821-834. https://doi.org/10.1175/BAMS-D-12-00066.1

Rudra, R., Ahmed, I., Khan, A. A., Singh, K. G., Goel, P. K., Khayer, M., \& Dickinson, T. (2015). Use of Baseflow Indices to Delineate Baseflow Dominated and Rapid Response 
Flow Dominated Watersheds. Canadian Biosystems Engineering, 57, 1.1-1.11. https://doi.org/10.7451/CBE.2015.57.1.1

Salmi, T., Määttä, A., Anttila, P., Ruoho-Airola, T., \& Amnell, T. (2002). Detecting Trends of Annual Values of Atmospheric Pollutants by the Mann-Kendall Test and Sen's Slope Estimates-The Excel Template Application MAKESENS: Finnish Meteorological Institute, Air Quality Research.

Shahid, M., \& Rahman, K. U. (2021). Identifying the Annual and Seasonal Trends of Hydrological and Climatic Variables in the Indus Basin Pakistan. Asia-Pacific Journal of Atmospheric Sciences, 57, 191-205. https://doi.org/10.1007/s13143-020-00194-2

Shahid, M., Cong, Z., \& Zhang, D. (2018). Understanding the Impacts of Climate Change and Human Activities on Streamflow: A Case Study of the Soan River Basin, Pakistan. Theoretical and Applied Climatology, 134, 205-219. https://doi.org/10.1007/s00704-017-2269-4

Upadhyay, R. K. (2020). Markers for Global Climate Change and Its Impact on Social, Biological and Ecological Systems: A Review. American Journal of Climate Change, 9, 159-203. https://doi.org/10.4236/ajcc.2020.93012

Vincent, L. A., Wang, X. L., Milewska, E. J., Wan, H., Yang, F., \& Swail, V. (2012). A Second Generation of Homogenized Canadian Monthly Surface Air Temperature for Climate Trend Analysis. Journal of Geophysical Research: Atmospheres, 117, Article ID: D18110. https://doi.org/10.1029/2012JD017859

Vincent, L., Zhang, X., Brown, R., Feng, Y., Mekis, E., Milewska, E. et al. (2015). Observed Trends in Canada's Climate and Influence of Low-Frequency Variability Modes. Journal of Climate, 28, 4545-4560. https://doi.org/10.1175/JCLI-D-14-00697.1

Von Storch, H., \& Navarra, A. (1995). Analysis of Climate Variability: Applications of Statistical Techniques. Springer-Verlag. https://doi.org/10.1007/978-3-662-03167-4

Wang, X., Huang, G., \& Liu, J. (2014). Projected Increases in Intensity and Frequency of Rainfall Extremes through a Regional Climate Modeling Approach. Journal of Geophysical Research: Atmospheres, 119, 13271-13286. https://doi.org/10.1002/2014JD022564

Wang, X., Huang, G., \& Liu, J. (2016). Observed Regional Climatic Changes over Ontario, Canada, in Response to Global Warming. Meteorological Applications, 23, 140-149. https://doi.org/10.1002/met.1541

Whitfield, P. H., \& Cannon, A. J. (2000). Recent Variations in Climate and Hydrology in Canada. Canadian Water Resources Journal, 25, 19-65. https://doi.org/10.4296/cwrj2501019

Zhang, X., Harvey, K. D., Hogg, W., \& Yuzyk, T. R. (2001). Trends in Canadian Streamflow. Water Resources Research, 37, 987-998. https://doi.org/10.1029/2000WR900357 